\title{
Perbandingan Hasil Belajar Materi Sistem Pencernaan Makanan Pada Model Pembelajaran Reciprocal Teaching yang Menggunakan Game Smart Case Dengan yang Tidak Menggunakan Game Smart Case Peserta Didik SMA Negeri 1 Barru
}

\section{The Comparison Learning Outcomes Digestive System Material In Reciprocal Teaching Learning Model Used Game Smart Case With Not Used Game Smart Case Students Sma Negeri 1 Barru}

\author{
Andi Irna Lestari Husni ${ }^{1}{ }^{*}$, Mushawwir Taiyeb ${ }^{1}$, Fatmah Hiola ${ }^{1}$ \\ ${ }^{1}$ Universitas Negeri Makassar, Jl. Malengkeri, Makassar, Indonesia \\ andi.irnalestarihusni@gmail.com
}

\begin{abstract}
This study aims to determine the comparison learning outcomes digestive system material in reciprocal teaching learning model used game smart case with not used game smart case students SMA Negeri 1 Barru. The sample in this research is the students of class XI MIA 4 as experiment class 1 and class XI MIA 7 as experiment class 2 which amounts to 70 students obtained by using simple purposive sampling technique. This research uses quasi experimental research design pretest-posttest non equivalen comparison group design. The cognitive learning outcomes were measured using a multiple choice test of 30 numbers and a description test of 5 numbers on the dietary material of the digestive system. The data obtained were analyzed by descriptive statistic and inferential statistic using paired sample anacova test with significance level 0,05 . The result of $t$ test statistic for students' cognitive learning result is 0,004 means Ho is rejected and H1 accepted so that it can be concluded that there is a comparison learning outcomes digestive system material in reciprocal teaching learning model used game smart case with not used game smart case students.
\end{abstract}

Keyword: game smart case, reciprocal teaching learning model, biology cognitive learning outcome

\section{PENDAHULUAN}

Pendidikan adalah salah satu faktor dalam meningkatkan kesejahteraan dan kualitas sumber daya manusia. Karakteristik abad 21 sebagai era globalisasi yang sangat dipengaruhi oleh perkembangan sains telah menempatkan pendidikan sains sebagai salah satu faktor penting dalam menciptakan masyarakat dengan kemampuan bersaing di dunia global. Melalui pendidikan sains yang bermutu, kompetensi masyarakat dapat berkembang dengan baik.

Tujuan pendidikan dapat tercapai dengan baik apabila seorang guru melakukan sistem pembelajaran yang sesuai dengan perkembangan kurikulum yang berlaku. Kurikulum yang disarankan pada saat ini adalah kurikulum 2013 yang merupakan hasil penyempurnaan dari Kurikulum Tingkat Satuan Pendidikan (KTSP) 2006. Kurikulum 2013 adalah kurikulum yang mengacu pada keseimbangan antara sikap, keterampilan dan pengetahuan untuk membangun soft skills dan hard skills.

Pembelajaran Biologi dalam kurikulum 2013 menekankan pada penerapan model-model pembelajaran yang dapat memungkinkan peserta didik untuk belajar lebih aktif, memahami apa yang dipelajarinya lebih baik dan meningkatkan kemampuan peserta didik sesuai dengan tujuan yang ingin dicapai, terutama untuk memahami materi yang dipelajarinya. Model pembelajaran yang inovatif akan mendukung peserta didik dalam memahami materi dengan baik.

Menurut Sanjaya (2008) pembelajaran adalah proses kerjasama antara guru dan peserta didik artinya sebagai suatu proses kerjasama pembelajaran tidak hanya menitikberatkan pada kegiatan guru atau kegiatan peserta didik saja, akan tetapi guru dan peserta didik secara bersama-sama mencapai tujuan pembelajaran yang telah ditentukan. Selain itu, proses pembelajaran yang dituntut oleh kurikulum 2013 untuk mencapai tujuan pendidikan nasional adalah pembelajaran aktif yang berpusat pada siswa (student centered), melibatkan interaksi dua arah antara guru dan peserta didik maupun sebaliknya sehingga terjadi pembelajaran yang bermakna dan berkesan bagi peserta didik. Proses pembelajaran adalah suatu pengalaman yang terjadi akibat interaksi antara peserta didik dengan lingkungannya termasuk guru dan teman sebaya yang menghasilkan perubahan dari peserta didik.

Berdasarkan hasil observasi awal peneliti menemukan bahwa hasil belajar peserta didik rendah yaitu $80 \%$ peserta didik tidak lulus nilai Kriteria Ketuntasan Minimum (KKM) mata pelajaran Biologi tahun ajaran 2016/2017. Hal ini dapat dikarenakan proses pembelajaran di kelas XI MIA SMA Negeri 1 
Barru berlangsung monoton. Guru menerapkan model pembelajaran langsung dengan hanya menggunakan buku paket dan Lembar Kerja Siswa (LKS). Guru menyampaikan materi pembelajaran, kemudian peserta didik diberikan kesempatan untuk mengisi LKS dan melakukan diskusi kelompok tanpa dibimbing oleh guru. Peserta didik tidak diberikan kesempatan untuk mengembangkan kemampuannya.

Model pembelajaran langsung yang seperti itu menyebabkan proses pembelajaran berlangsung pasif (teacher centered). Guru sebagai pusat pembelajaran yang menyampaikan materi secara terus menerus dan peserta didik hanya mendengarkan materi yang disampaikan oleh guru. Oleh karena itu dibutuhkan model pembelajaran yang inovatif yang dapat mengaktifkan peserta didik.

Salah satu model pembelajaran yang digunakan agar peserta didik sebagai subyek belajar dapat berperan aktif dalam proses pembelajaran adalah model pembelajaran reciprocal teaching. Model pembelajaran reciprocal teaching merupakan model pengajaran terbalik yang menekankan peserta didik bertindak sebagai guru dalam diskusi dan guru hanya sebagai fasilitator serta pembimbing. Peserta didik memiliki kesempatan untuk mengembangkan kemampuannya seperti menyampaikan ide dan berpikir kritis. Sehingga proses pembelajaran berlangsung aktif (student centered) dan peserta didik dapat berpikir, berdiskusi, menyampaikan pendapat dan membuat kesimpulan.

Lubriner (2001) berpendapat bahwa reciprocal teaching adalah suatu metode intruksi membaca yang diajarkan kepada peserta didik untuk menggunakan strategi tanya jawab, menjelaskan, meringkas, dan penggambaran kesimpulan dalam suatu dialog berbasis bacaan. Sejalan dengan itu Jones (1999) berpendapat bahwa reciprocal teaching juga mengacu pada suatu aktivitas yang berlangsung dalam wujud dialog antara guru dan siswa mengenai segmen teks. Dialog tersusun oleh penggunaan empat strategi yang terdiri dari peringkasan, tanya jawab, penjelasan, dan penggambaran kesimpulan.

Model pembelajaran reciprocal teaching lebih menarik dan bermakna bagi peserta didik jika dipadukan dengan menggunakan permainan game smart case. Permainan ini memerlukan persiapan berupa: soal-soal untuk materi prasyarat, nomor undian yang dimasukkan dalam kotak (case), kartu pintar dan penghargaan (reward). Kartu pintar berisi gambar tentang materi kajian dan soal dalam bahasa Indonesia. Oleh karena itu penulis menggunakan model pembelajaran yang dapat meningkatkan hasil belajar kognitif peserta didik yaitu model pembelajaran reciprocal teaching dengan dipadukan game smart case.

Game smart case merupakan permainan edukatif yang mampu menciptakan suasana dalam pembelajaran lebih menarik dan peserta didik lebih aktif (Faozan, 2009). Tujuan dari permainan edukatif adalah untuk mengembangkan komunikasi, mengembangkan aspek fisik dan motorik, mengembangkan aspek emosi dan kepribadian, aspek sosial serta kreativitas. Salah satu permainan edukatif adalah game smart case atau yang disebut juga permainan kotak pintar (Munadi, 2012).

Berdasarkan ulasan latar belakang tersebut, maka peneliti melaksanakan penelitian dengan judul "Perbandingan Penggunaan Game Smart Case Pada Model Pembelajaran Reciprocal Teaching Terhadap Hasil Belajar Kognitif Biologi Peserta Didik Pada Materi Sistem Pencernaan Makanan SMA Negeri 1 Barru".

Berdasarkan uraian di atas, maka rumusan masalah yang diteliti dalam penelitian ini adalah

1. Bagaimana hasil belajar kognitif peserta didik yang dibelajarkan model pembelajaran reciprocal teaching yang menggunakan game smart case materi sistem pencernaan makanan?

2. Bagaimana hasil belajar kognitif peserta didik yang dibelajarkan model pembelajaran reciprocal teaching tanpa menggunakan game smart case materi sistem pencernaan makanan?

3. Bagaimanakah perbandingan hasil belajar kognitif peserta didik yang dibelajarkan menggunakan model pembelajaran reciprocal teaching yang menggunakan game smart case dengan yang tidak menggunakan game smart case materi sistem pencernaan makanan?

Berdasarkan rumusan masalah tersebut, maka tujuan yang akan dicapai dalam penelitian ini adalah

1. Mengetahui hasil belajar kognitif peserta didik yang dibelajarkan model pembelajaran reciprocal teaching yang menggunakan game smart case materi sistem pencernaan makanan?

2. Mengetahui hasil belajar kognitif peserta didik yang dibelajarkan model pembelajaran reciprocal teaching tanpa menggunakan game smart case materi sistem pencernaan makanan?

3. Mengetahui perbandingan hasil belajar kognitif peserta didik yang dibelajarkan menggunakan model pembelajaran reciprocal teaching yang menggunakan game smart case dengan yang tidak menggunakan game smart case materi sistem pencernaan makanan?

\section{METODE PENELITIAN}

Jenis penelitian ini adalah penelitian penelitian eksperimen semu (quasi exsperimental). Penelitian ini telah dilaksanakan saat mulai validasi instrumen pada tanggal 19 desember 2017 - 3 januari 2018 dan sampai dilakukan penelitian di sekolah yaitu pada tanggal 8 31 januari 2018 semester genap tahun pelajaran 2017/2018 dan berlokasi di sma negeri 1 barru. Populasi pada penelitian ini adalah seluruh peserta didik kelas xi mia sma negeri 1 barru yang terdiri dari 7 kelas (rombongan belajar). Sampel penelitian ini adalah kelas xi mia 4 sebagai kelas eksperimen 1 dan kelas xi mia 7 sebagai kelas eksperimen 2. Alokasi waktu untuk proses pembelajaran 3 kali pertemuan dan 2 kali pertemuan untuk melaksanakan evaluasi (pretest) dan (posttest) serta 1 kali pertemuan untuk melaksanakan praktikum uji makanan. Materi yang diajarkan adalah sistem pencernaan makanan. 


\section{Pembelajaran Reciprocal Teaching......}

Instrumen yang digunakan dalam penelitian ini adalah tes hasil belajar kognitif berupa soal pilihan ganda sebanyak 30 soal dan tes uraian sebanyak 5 nomor yang sudah divalidasi oleh validator ahli untuk mengukur hasil belajar kognitif peserta didik yang dirancang berdasarkan indikator pembelajaran.

Hasil belajar kognitif yang telah diperoleh dianalisis secara deskriptif dan inferensial dengan menggunakan sistem Statistical Package for Social Sciense (SPSS) versi 22.0. Analisis statistik deskriptif bertujuan untuk mendeskripsikan hasil belajar kognitif biologi yang diperoleh peserta didik baik pada kelas eksperimen 1 (game smart case pada model pembelajaran reciprocal teaching) maupun kelas eksperimen 2 (reciprocal teaching).

Analisis statistik inferensial digunakan untuk menguji hipotesis penelitian dengan menggunakan analisis uji anacova melalui sistem SPSS dengan taraf signifikansi $\alpha=0,05$. Kriteria pengujian adalah jika sig. (2-tailed) $>\alpha 0,05$, maka $\mathrm{H}_{0}$ diterima dan $\mathrm{H}_{1}$ ditolak, berarti tidak terdapat perbandingan hasil belajar kognitif peserta didik materi sistem Tabel 1 Deskripsi Nilai Pretest-Posttest Peserta Didik pada Kelas Eksperimen 1 dan Kelas Eksperimen 2 Hasil Belajar

\begin{tabular}{|c|c|c|c|c|}
\hline \multirow[t]{2}{*}{ Statistik } & \multicolumn{2}{|c|}{ Kelas Eksperimen 1} & \multicolumn{2}{|c|}{ Kelas Eksperimen 2} \\
\hline & Pretest & Posttest & Pretest & Posttest \\
\hline Ukuran Sampel & 35 & 35 & 35 & 35 \\
\hline Median & 20,00 & 85,00 & 14,50 & 81,65 \\
\hline Standar Deviasi & 5,96 & 4,13 & 5,22 & 5,92 \\
\hline Rata-rata & 19,75 & 85,63 & 15,56 & 80,93 \\
\hline Nilai Terendah & 6,00 & 77,80 & 7,15 & 77,15 \\
\hline Nilai Tertinggi & 35,80 & 92,65 & 27,65 & 92,50 \\
\hline \multicolumn{5}{|c|}{$\begin{array}{l}\text { Tabel } 1 \text { menunjukkan bahwa nilai rata-rata hasil belajar peserta didik pada kelas eksperimen } 1 \text { dan } \\
\text { eksperimen } 2 \text { mengalami peningkatan sebelum dan sesudah dibelajarkan dengan model pembelajaran reciprocal } \\
\text { teaching yang menggunakan game smart case dengan yang tidak menggunakan game smart case. Tetapi jika } \\
\text { ditinjau dari kedua kelompok tersebut, kelas yang dibelajarkan dengan game smart case pada model pembelajaran } \\
\text { reciprocal teaching memiliki nilai rata-rata yang lebih tinggi yaitu 85,63 dibandingkan dengan nilai rata-rata dari } \\
\text { kelas yang dibelajarkan dengan model pembelajaran reciprocal teaching yaitu } 80,93 \text {. Nilai dari hasil belajar } \\
\text { peserta didik selanjutnya dikelompokkan berdasarkan pengkategorian hasil belajar. Distribusi frekuensi dan } \\
\text { persentasi hasil belajar peserta didik menggunakan game smart case pada model pembelajaran reciprocal teaching } \\
\text { dan reciprocal teaching dapat dilihat pada Tabel } 2\end{array}$} \\
\hline
\end{tabular}

Tabel 1 menunjukkan bahwa nilai rata-rata hasil belajar peserta didik pada kelas eksperimen 1 dan eksperimen 2 mengalami peningkatan sebelum dan sesudah dibelajarkan dengan model pembelajaran reciprocal teaching yang menggunakan game smart case dengan yang tidak menggunakan game smart case. Tetapi jika ditinjau dari kedua kelompok tersebut, kelas yang dibelajarkan dengan game smart case pada model pembelajaran reciprocal teaching memiliki nilai rata-rata yang lebih tinggi yaitu 85,63 dibandingkan dengan nilai rata-rata dari kelas yang dibelajarkan dengan model pembelajaran reciprocal teaching yaitu 80,93. Nilai dari hasil belajar peserta didik selanjutnya dikelompokkan berdasarkan pengkategorian hasil belajar. Distribusi frekuensi dan persentasi hasil belajar peserta didik menggunakan game smart case pada model pembelajaran reciprocal teaching dan reciprocal teaching dapat dilihat pada Tabel 2 reciprocal teaching yang menggunakan game smart tailed) 0,05 . berarti tidak terdapat perbandingan penggunaan game smart case pada model pembelajaran reciprocal teaching terhadap hasil belajar kogntif biologi peserta

\section{HASIL DAN PEMBAHASAN}

Analisis Statistik Deskriptif Hasil Belajar Kognitif Analisis statistik deskriptif bertujuan untuk mendeskripsikan hasil belajar peserta didik setelah mempelajari materi sistem pencernaan makanan pada pembelajaran reciprocal teaching yang menggunakan game smart case. Data hasil belajar peserta didik diperoleh dari nilai pretest dan posttest seperti dapat dilihat pada Tabel 4.1. pencernaan makanan pada model pembelajaran 
Tabel 4.2 Distribusi Frekuensi Tingkat Hasil Belajar Biologi dan Persentase Skor Pretest-Posttest Peserta Didik Pada Kelas Eksperimen 2 dan Kelas Eksperimen 1

\begin{tabular}{|c|c|c|c|c|c|c|c|c|c|}
\hline \multirow[t]{3}{*}{ Interval } & \multirow[t]{3}{*}{ Kategori } & \multicolumn{4}{|c|}{ Eksperimen 1} & \multicolumn{4}{|c|}{ Eksperimen 2} \\
\hline & & \multicolumn{2}{|c|}{ Pretest } & \multicolumn{2}{|c|}{ Posttest } & \multicolumn{2}{|c|}{ Pretest } & \multicolumn{2}{|c|}{ Posttest } \\
\hline & & $\mathrm{F}$ & $(\%)$ & $\mathrm{F}$ & $(\%)$ & $\mathrm{F}$ & $(\%)$ & $\mathrm{F}$ & $(\%)$ \\
\hline $80-100$ & $\begin{array}{l}\text { Sangat } \\
\text { Baik }\end{array}$ & 0 & 0,00 & 32 & 91,43 & 0 & 0,00 & 22 & 62,86 \\
\hline $66-79$ & Baik & 0 & 0,00 & 3 & 8,57 & 0 & 0,00 & 13 & 37,14 \\
\hline $56-65$ & Cukup & 0 & 0,00 & 0 & 0,00 & 0 & 0,00 & 0 & 0,00 \\
\hline $40-55$ & Kurang & 0 & 0,00 & 0 & 0,00 & 0 & 0,00 & 0 & 0,00 \\
\hline 0-39 & $\begin{array}{l}\text { Sangat } \\
\text { kurang }\end{array}$ & 35 & 100 & 0 & 0 & 35 & 100 & 0 & 0,00 \\
\hline \multicolumn{2}{|c|}{ Jumlah } & 35 & 100 & 35 & 100 & 35 & 100 & 35 & 100 \\
\hline
\end{tabular}

Tabel 2 menunjukkan bahwa persentase hasil belajar peserta didik pada pretest kelas eksperimen 1 dan eksperimen 2 sama-sama berada pada kategori sangat kurang. Tetapi setelah dilakukan posttest, menunjukkan adanya peningkatan hasil belajar dimana pada kedua kelas didominasi pada kategori sangat baik. Hasil dari persentase tersebut menunjukkan bahwa hasil belajar kognitif peserta didik setelah dibelajarkan model reciprocal teaching yang menggunakan game smart case dengan yang tidak menggunakan game smart case memiliki peningkatan hasil belajar yang sama.

Analisis Statistik Inferensial Hasil Belajar Kognitif Analisis statistik inferensial digunakan untuk menguji hipotesis dalam penelitian, yaitu terdapat perbandingan hasil belajar kognitif peserta didik materi sistem pencernaan makanan pada model pembelajaran reciprocal teaching yang menggunakan game smart case dengan yang tidak menggunakan game smart case SMA Negeri 1 Barru. Untuk menguji hipotesis digunakan analisis inferensial dengan uji ANACOVA (Analysis of Covariance).

Adapun syarat yang harus dipenuhi untuk pengujian hipotesis adalah data yang diperoleh berdistribusi normal dan mempunyai variansi yang homogen, sebelum dilakukan pengujian hipotesis terlebih dahulu dilakukan analisis prasyarat yaitu uji normalitas dan uji homogenitas. Setelah data diolah dan dilakukan pengujian terhadap uji normalitas dan uji homogenitas dari populasi data dan dinyatakan normal serta homogen, maka selanjutnya data dilakukan uji hipotesis. Pengujian data yang digunakan adalah uji anacova yang dapat dilihat pada Tabel 3.

Tabel 3 Hasil Uji ANCOVA Pada Subjects Effects

Tests of Between-Subjects Effects

Dependent Variable: Posttest

\begin{tabular}{|c|c|c|c|c|c|}
\hline & $\begin{array}{c}\text { Type III Sum of } \\
\text { Squares }\end{array}$ & df & Mean Square & F & Sig. \\
\hline Corrected Model & $470.200^{\mathrm{a}}$ & 2 & 235.100 & 9.314 & .000 \\
Intercept & 39743.926 & 1 & 39743.926 & 1574.523 & .000 \\
Pretest & 83.201 & 1 & 83.201 & 3.296 & .074 \\
Model & 229.341 & 1 & 229.341 & 9.086 & .004 \\
Error & 1691.206 & 67 & 25.242 & & \\
Total & 487732.111 & 70 & & & \\
Corrected Total & 2161.405 & 69 & & & \\
\hline
\end{tabular}

Dari output di atas terlihat bahwa nilai signifikansi untuk variabel model adalah 0,004 karena nilai signifikansi yaitu $0,004<0,05$ maka $\mathrm{H}_{0}$ ditolak yang berarti $\mathrm{H}_{1}$ diterima, sehingga dapat disimpulkan bahwa pada tingkat kepercayaan 95\% terdapat perbandingan yang signifikan untuk hasil belajar kognitif yang diajar dengan model pembelajaran reciprocal teaching yang menggunakan game smart case dengan yang tidak menggunakan game smart case.
Penelitian ini adalah penelitian tentang perbandingan hasil belajar kognitif peserta didik materi sistem pencernaan makanan pada model pembelajaran reciprocal teaching yang menggunakan game smart case dengan yang tidak menggunakan game smart case SMA Negeri 1 Barru. Pada penelitian ini menggunakan dua kelas yaitu XI MIA 4 sebagai kelas eksperimen 1 yang dibelajarkan menggunakan game smart case pada model pembelajaran reciprocal teaching dan XI MIA 7 sebagai kelas eksperimen 2 
yang dibelajarkan menggunakan model pembelajaran reciprocal teaching. Model pembelajaran reciprocal teaching (pengajaran terbalik) merupakan salah satu model pembelajaran kooperatif yang menuntut peserta didik belajar secara berkelompok yang menekankan peserta didik bertindak sebagai guru dalam diskusi dan guru sebagai fasilitator dan pembimbing. Kemudian dipadukan dengan permainan yaitu game smart case yang merupakan permainan edukatif yang mampu menciptakan suasana dalam pembelajaran lebih menarik dan tidak membosankan.

Berdasarkan hasil analisis statistik deskriptif, diperoleh nilai rata-rata pretest hasil belajar kognitif peserta didik pada kelas eksperimen 1 yaitu 19,75 sedangkan pada kelas eksperimen 2 yaitu 15,56. Hasil belajar kognitif peserta didik tersebut pada kedua kelas sama-sama berada pada kategori sangat kurang dengan interval nilai $0-39$. Hal ini menunjukkan bahwa kemampuan awal peserta didik pada kedua kelas sebelum diberi perlakuan (berupa model pembelajaran) adalah sama. Nilai rata-rata posttest hasil belajar kognitif peserta didik pada kelas eksperimen 1 yaitu 85,63 sedangkan pada kelas eksperimen 2 yaitu 80,93. Hasil belajar kognitif peserta didik tersebut pada kedua kelas berada pada kategori sangat baik dengan interval nilai 80-100. Hal ini menunjukkan bahwa terdapat peningkatan hasil belajar kognitif peserta didik setelah diberi perlakuan dengan penggunaan game smart case pada model pembelajaran reciprocal teaching dan model pembelajaran reciprocal teaching.

Model pembelajaran reciprocal teaching pada kedua kelas memberi pengaruh positif yaitu dapat meningkatkan hasil belajar kognitif peserta didik dari nilai pretest ke nilai posttest. Hal ini sejalan dengan penelitian yang dilakukan Effendi (2013) yang menunjukkan bahwa melalui penerapan model pembelajaran reciprocal teaching mampu meningkatkan hasil belajar peserta didik mencapai $92,5 \%$ yang tuntas. Sejalan dengan ini, Wilujeng (2000) juga melakukan penelitian yang serupa bahwa model pembelajaran reciprocal teaching melatih kemandirian belajar peserta didik.

Penggunaan game smart case memberikan perbandingan yang lebih nyata karena peserta didik yang dibelajarkan menggunakan game smart case pada model pembelajaran reciprocal teaching memiliki nilai hasil belajar kognitif yang lebih tinggi dibandingkan dengan peserta didik yang dibelajarkan hanya menggunakan model pembelajaran reciprocal teaching (tanpa game smart case). Peserta didik pada dasarnya menyukai game, ketika diberikan game yaitu game smart case pada model pembelajaran reciprocal teaching saat proses pembelajaran maka motivasi peserta didik tinggi. Ketika motivasi peserta didik tinggi, maka aktivitas peserta didik menjadi meningkat sehingga peserta didik lebih antusias dan bersemangat dalam belajar. Dalam game smart case memberikan tambahan pengetahuan peserta didik berupa soal prasayarat dan smart card dalam permainan. Sejalan dengan penelitian Lazarus (2015) yang menunjukkan bahwa melalui penerapan model pembelajaran reciprocal teaching dengan permainan game smart case pada materi biologi dari siklus I ke siklus II mengalami peningkatan yaitu pada minat belajar dan ketuntasan hasil belajar peserta didik. Minat belajar peserta didik pada siklus I berada pada kategori cukup, siklus II berada pada kategori baik. Sedangkan ketuntasan hasil belajar peserta didik pada siklus I yaitu 48,3\%, siklus II mencapai $83,3 \%$. Hal ini juga sejalan dengan penelitian Zulkarnaeni (2016) bahwa nilai hasil belajar peserta didik tinggi apabila didukung oleh aktivitas belajar peseta didik meningkat.

Aktivitas belajar peserta didik meningkat apabila motivasi belajar peserta didik tinggi dan didukung oleh model pembelajaran yang aktif. Hal ini sejalan dengan penelitian yang dilakukan oleh Effendi (2013) bahwa hasil belajar peserta didik meningkat apabila didukung oleh respon minat dan motivasi belajar peserta didik yang tinggi. Taiyeb (2012) juga mengatakan bahwa motivasi belajar peserta didik mempengaruhi hasil belajar peserta didik sekitar $83,75 \%$. Berdasarkan asusmsi yang telah dikemukakan bahwa selain model pembelajaran, ada beberapa faktor yang mempengaruhi hasil belajar kognitif peserta didik diantaranya motivasi dan aktivitas.

Motivasi tinggi, aktivitas meningkat, serta model pembelajaran yang aktif memiliki hubungan yang sangat erat. Dalam penelitian ini, penggunaan game smart case pada model pembelajaran reciprocal teaching menjadikan peserta didik lebih antusias dalam belajar yaitu dengan adanya aktivitas game, sehingga peserta didik lebih termotivasi dalam belajar. Terlihat pada pertemuan pertama saat memperkenalkan game smart case, peserta didik sangat bersemangat mendengarkan aturan dalam permainan game smart case ini. Dalam permainan ini juga peserta didik diberikan soal-soal berupa pilihan ganda (soal prasyarat) dan soal yang ada di dalam smart card sehingga memberikan tambahan pengetahuan kognitif bagi peserta didik itu sendiri. Sedangkan penggunaan model pembelajaran reciprocal teaching tanpa game smart case, peserta didik juga termotivasi dalam belajar namun aktivitas peserta didik kurang. Aktivitas peserta didik kurang karena tidak ada game yang diberikan. Peserta didik melakukan diskusi tanpa permainan game smart case, sehingga tambahan pengetahuan kognitif peserta didik juga kurang karena tidak ada pemberian berupa soal prasyarat (pilihan ganda) dan smart card.

Berdasarkan penelitian yang telah dilakukan, maka dapat disimpulkan bahwa terdapat perbandingan hasil belajar kognitif peserta didik materi sistem pencernaan makanan pada model pembelajaran reciprocal teaching yang menggunakan game smart case dengan yang tidak menggunakan game smart case. Kedua kelas menggunakan model pembelajaran reciprocal teaching mampu meningkatkan hasil 
belajar kognitif peserta didik dari pretest ke posttest. Namun melalui penggunaan game smart case pada kelas eksperimen 1 memberikan perbandingan hasil belajar kognitif yang lebih tinggi dibandingkan dengan yang tidak menggunakan game smart case pada materi sistem pencernaan makanan.

\section{SIMPULAN}

Berdasarkan hasil dan pembahasan pada penelitian ini, maka dapat diperoleh kesimpulan yaitu

1. Model pembelajaran reciprocal teaching yang menggunakan game smart case meningkatkan hasil belajar kognitif peserta didik pada materi sistem pencernaan makanan dengan nilai ratarata 85,63 .

2. Model pembelajaran reciprocal teaching tanpa menggunakan game smart case juga meningkatkan hasil belajar kognitif peserta didik pada materi sistem pencernaan makanan dengan nilai rata-rata 80,93 .

3. Penggunaan game smart case memberikan perbandingan hasil belajar kognitif yang lebih tinggi dibandingkan yang tidak menggunakan game smart case pada materi sistem pencernaan makanan.

\section{DAFTAR PUSTAKA}

Abdurrahman. (2007). Meaningfull Learning Reinvensi Kebenaran Pembelajaran. Yogyakarta: Pustaka Pelajar.

Allen, S. (2003). An Analytic Comparison of Three Models of Reading Strategy Instruction. IRAL: International Review of Applied Linguistics in Language Teaching., 41(4), 319-339.

Anderson \& Krathwohl (Ed.). (2010). Kerangka Landasan Untuk Pembelajaran, Pengajaran, dan Asesmen (Terjemahan oleh Agung Prihantoro). Yogyakarta: Pustaka Pelajar.

Arikunto, Suharsimi. (2013). Dasar-dasar Evaluasi Pendidikan. Jakarta: Bumi Aksara

Arikunto, Suharsimi. (2005). Manajemen Penelitian. Jakarta: Rineka Cipta.

Dimyati \& Moedjiono. (2006). Belajar dan Pembelajaran. Jakarta: Rineka Cipta.

Djamarah, Syaiful Bahri. (2006). Strategi Belajar Mengajar. Jakarta: Rineka Cipta.

Effendi, Nur. (2013). Pendekatan Pengajaran Reciprocal Teaching Berpotensi Meningkatkan Ketuntasan Hasil Belajar Biologi Siswa SMA. Jurnal Pendidikan. Sidoarjo: Universitas Muhammadiyah Sidoarjo.

Faozan, Ahmad. (2009). Penggunaan Metode Game Smart dan Pembelajaran Kooperatif Tipe Make A Match dalam Pembelajaran Nama-nama dan Tugas-tugas Malaikat Allah. Surabaya: Universitas Negeri Surabaya.

Haling, Abdul. (2007). Belajar dan Pembelajaran. Makassar: Universitas Negeri Makassar.

Hamalik, Oemar. (1994). Kurikulum dan Pembelajaran. Jakarta: Bumi Aksara.
Hamalik, Oemar. (2011). Proses Belajar Mengajar. Jakarta: Bumi Aksara.

Hamdayama, Jumanta. (2016). Metodologi Penelitian. Jakarta: Bumi Aksara.

Hashey, J. M., \& Connors, D. J. (2003). Learn from Our Journey: Reciprocal Teaching Action Research. Reading Teacher., 57(3), 224-233.

Hornby, A. S. (1974). Oxford Adventure Learner's Dictionary of Current English. London: Oxford University Press.

Jones, R. (1999). Strategies for Comprehension Reciprocal Teaching. Htp:/www.curry.Edschool.virginia.edu/gd.readg uest/star/rt.html.

Kemendikbud. (2015). Panduan Penilaian: Untuk Sekolah Menengah Atas. Jakarta: Direktorat Jenderal Pendidikan Dasar dan Menengah.

Lazarus. (2015). Penerapan Model Pembelajaran Reciprocal Teaching dengan Game Smart Case Untuk Meningkatkan Minat Belajar dan Ketuntasan Belajar Siswa Kelas VIII Pokok Materi Sistem Ekskresi Di SMPN 13 Malang. Jurnal Pendidikan. Malang: IKIP Budi Utomo Malang.

Lubriner. (2001). Reciprocal Teaching An Alternatif To Gate Keeping Practices. Http:/www.ased.org/aboutased/er/student/author /0111/lubriber.htm.

Minoy, J. (2002). Penerapan Model Pembelajaran Reciprocal Teaching Menggunakan Strategi Elaborasi Pada Pokok Bahasan Penyajian Data Statistik. Makalah. Disajikan dalam Penelitian TOT Pembelajaran Kontekstual (CTL) Untuk Instruktur Guru dan Dosen dari 24 Provinsi. Departemen Pendidikan Nasional. Bogor, Surabaya, dan Medan. September-November.

Munadi, Yudhi. (2008). Faktor yang Mempengaruhi Hasil Belajar. Jakarta: Gaung Persada Press.

Munadi, Yudhi. (2012). Belajar Biologi dengan Game Smart. Surabaya: Universitas Negeri Surabaya.

Nur, M. (2000). Strategi-strategi Belajar. Surabaya: Universitas Negeri Surabaya.

Nur, M., \& Wikandari. (2000). Strategi-strategi Belajar. Surabaya: Universitas Negeri Surabaya.

Palincsar, A. S., \& Brown, A. L. (1984). Reciprocal Teaching of Comprehension-Fostering and Comprehension-Monitoring Activities Cognition and Instruction., 2, 117-175.

Pujiastuti, E. (2000). Penerapan Pembelajaran Terbalik (Reciprocal Teaching) dalam Perkuliahan di Jurusan Matematika Sebagai Wahana Peningkatan Kemampuan Mahasiswa Belajar Mandiri. Jurnal Matematika. Semarang: Universitas Negeri Semarang.

Pusat Kurikulum. (2006). Pembelajaan Tematik. Jakarta: Departemen Pendidikan Nasional.

Purwanto. (2009). Evaluasi Hasil Belajar. Yogyakarta: Pustaka Pelajar.

Sanjaya, Wina. (2008). Perencanaan dan Desain Sistem Pembelajaran. Jakarta: Kencana Prenada Media Group.

Slameto. (2003). Belajar dan Faktor-faktor yang Mempengaruhinya. Jakarta: Rineka Cipta. 
Sugiyono. 2015. Metode Penelitian Kuantitatif, Kualitatif, dan R\&D. Bandung: Alfabeta.

Suharno. (2013). Prinsip-prinsip Pembelajaran. Jakarta: Bumi Aksara.

Supardi. (2015). Penelitian Autentik. Jakarta: Bumi Aksara.

Suprijono, A. (2009). Cooperative Learning Theory dan Aplikasi Paikem. Surabaya: Pustaka Pelajar.

Taiyeb, M., Bahri Arsad \& Batari Rezky. (2012). Analisis Motivasi Berprestasi Siswa SMAN 8 Makassar dalam Belajar Biologi. Jurnal Bionature UNM., 13 (2), 77-82.

Taiyeb, M., \& Mukhlisa, N. (2015). Hubungan Gaya Belajar dan Motivasi Belajar dengan Hasil Belajar Biologi Siswa Kelas XI IPA SMA Negeri
1 Tanete Rilau. Jurnal Bionature UNM., 16 (1), 8-16.

Tim Pengembang MKDP Kurikulum dan Pembelajaran. (2015). Kurikulum dan Pembelajaran ( $2^{\text {nd }}$ ed.). Jakarta: Rajawali Press.

Wilujeng, I. (2000). Reciprocal Teaching Sebagai Upaya Melatih Kemandirian Siswa dalam Proses Belajar IPA. Jurnal Pendidikan Matematika., 3(3), 45-51.

Zulkarnaeni, Hala Yusminah, \& Taiyeb, M. (2016). Pengaruh Model Pembelajaran Berbasis Masalah dengan Pendekatan Kontekstual terhadap Aktivitas dan Hasil Belajar IPA Biologi Siswa Kelas VII SMP Negeri 1 Sibulue. Jurnal Nalar Pendidikan. Makassar: Pascasarjana Universitas Negeri Makassar. 